\title{
Not yet a requiem
}

\section{Abstract}

In 1966 the first congress of the history of oceanography was convened in Monaco and harvested a considerable success. The 50th anniversary of that event was to be celebrated this year [2016]. Dark clouds were menacing the festivities of actually taking place and 2016 might have been rather the celebration of a requiem of an otherwise very successful venue. Some salvation winds from down under brought some respite.

There is in the Section of the history and philosophy of sciences a Commission of oceanography that has done good work for fifty years and hasset up successful congresses about every luster and backed up solid proceedings books of the achievements. If a call for competitors towards a creative idea in the mid-sixties, in the marine sciences, had been uttered,"le commandant" J-Y. Cousteau would surely be among the toprunners in the "idea competition". Not only because of his books, films, and claims to fame, but even because of the controversies he unleashed in the academic, literary, scientific, artistic, legal and political domains. Just realizeFrance barely missed a Cousteau-for president try.

Had it not been for his idea to join another inventor, Gagnan, we would not have today the self- contained underwater breathing apparatus, the SCUBA of sportsmen and of scientists. And we would not have made huge progress in tapping the ocean for scores of natural products that play a primordial role, for instance, in developing medications to combat cancer, dengue, HIV, malaria, and several other ailments.

Cousteau pulled up from dusty indifference the Musee Oceanographique de Monaco. It was not uncommon for the hurried tourist to the tiny "onthe-rock" (le rocher, as the French and monegasques call it) Mediterranean principality, to throw a blasé look at the rusting carcass of Conshelf on the grass plot next to the museum, a forlorn "once-actor" of some of JacquesYves' films and bypass the principality's remarkable "tropical gardens" as well as the museum, to rather plunge into the Casino, "den of perdition". So, the showman in the commandant baptized two dolphins Romeo and Juliet and gave them some water space in the venerable but vetust structure that had been the pride, and one of the marine sciences working areas of Albert I, the prince-sovereign that was a passionate oceanographer, and actually had carved oceanographic milestones in stone by adorning the museum's facade with stone images of the prows of famed research vessels. 1 If tourists were indifferent to corers and alcohol tubes containing biological samples Albert I had collected during his oceanic campaigns, meeting Romeo and his mate, then getting onto a lift to the roof of the museum to sip an ice-cold drink while taking in an impregnable view of the Mediterranean sea-and-land paysage, now there was something to tell the folks back home, all of it agreemented with pictures, and why not draped in a sweatshirt displaying the name of the museum, that of the country and perhaps a picture of the museum, bought at its entrance from the very Madame Simone Cousteau, whom some had met in the pages of the American periodical National Geographic enjoying a flute of champagne with Jacques-Yves on their 25th wedding anniversary in an underwater habitat on the bed of the Red Sea.

In 1966, Cousteau had still another idea: why not call a symposium, conference or congress dealing with the history of oceanography centered on the Monaco museum? Now there might be some controversy about who had the idea or the precise date it germinated and Eric MILLS credits others in his listing of the "editions" of the congresses that actually took place

\section{A scapa flow show now?}

The rather limited attendance of the otherwise excellent 8th Congress was foreboding the effects of financial restrictions,yet the cancellation of the 9th meeting came as a big disappointment. The
Volume 7 Issue 2 - 2018

\section{Roger H Charlier,' Marie Claire P Chaineux, ${ }^{2}$ Constance $\mathrm{C}$ Charlier ${ }^{3}$ \\ 'Proffesor Emeritus,Vrije Universiteit Brussel (VUB), Belgium \\ ${ }^{2}$ Catholic University Mons (FUCAM), Belgium \\ ${ }^{3}$ University of Arizona, Axelrod Management Advisors, USA}

Correspondence: Roger H Charlier, Proffesor Emeritus,Vrije Universiteit Brussel(VUB), Belgium,

Email Roger.Charlier@vub.ac.be

Received: March 08, 2018 | Published: April 05, 2018

(Table 1); it remains my belief that Cousteau was the "cheville ouvriere" who gave the impetus to the "launching of the vessel" fully backed by the then sovereign Rainier III (1949-2005; born 1923). Nevertheless, it is only fair to recall that Jean THEODORIDES, medicine historian, came up with the idea, in 1962, at an assembly of the International Union of the History and Philosophy of Science (IUHPS), to hold a meeting devoted to the history of marine biological stations.2,3 Sufficient enthusiasm was generated for such a meeting that the first took place at Banyuls-sur-Mer (France) in 1963. The scope was promptly extended to the entire field of oceanography and the Premier Congres International de 'Histoire de' Oceanography welcomed a large group of scientists in Monaco in 1966. It heralded a cohort of seven more very successful congresses and at least three remarkable books actually Proceedings.4-6 Regrettably the 6th Congress (Museum of the World) has limited itself to a Russian translation of the unpublished English language Abstracts submitted to the congress. The ICHO also led to the publication under Eric Mills', of Dalhousie University, leadership of a much appreciated Newsletter.

Table I: Listing according to date held of ICHO congresses (1966-20I6).

\begin{tabular}{llllll}
\hline $\begin{array}{l}\text { Ordinal } \\
\text { Number }\end{array}$ & City & Country & Year & Years & Span \\
\hline 1 & Monaco & Monaco & 1966 & 0 & \\
2 & Edinburgh & Scotland & 1972 & 6 & \\
3 & Woods Hole MA & USA & 1980 & 8 \\
4 & Hamburg FR & Germany & 1987 & 7 \\
5 & La Jolla CA & USA & 1993 & 6 \\
6 & Qingdao PR & China & 1998 & 5 \\
7 & Kaliningrad & Russia RF & 2003 & 5 \\
8 & Naples & Italy & 2008 & 5 \\
9 & Athens & Greece & $2012 ?$ & 4 \\
10 & Tonsley & Australia & $2016 ?$ & 4 \\
\hline \multicolumn{5}{c}{$(?=$ canceled or which may be canceled) } \\
\end{tabular}

meeting had been scheduled to be held in Athens in 2012 but that was without taking fully into consideration the difficulties created by the financial clouds threatening the hellenic organizers. Thence ICHO-IX simply faded away in the hope that more favorable skies would soon unfold. Unfortunately things have not improved to a sufficient extent 
over the Acropolis. On the ICHO horizon even the Annual Newsletter was not able to weather the storm and "folded", leaving room only for a modest personal individual's blog. Granted, of high quality and fascinating content.

Flinders University of Tonsley (Australia) came to the rescue: it was the first Australian university to offer graduate degrees in oceanography, but furthermore 2016 is the year of its silver anniversary; 2016 is also the year of the 50th birthday of ICHO! But, alas Australia is far for most of us and fares expensive, so newly elected president Walter Lenz $\mathrm{z}^{7-9}$ informed Roger Charlier that "interest" has been low for a multiple day meeting; the conference in Greater Adelaide on the theme "Discovering changes in the oceans of the world" for April 1215,2016 is thus also in jeopardy. Will it be scuttled like a fleet once was at Scapa Flow and perhaps a mere memorial book take its place?

\section{Quid nunc ICHO?}

\section{Happy ending (at least for a while)}

The marine deities cajoled the winds in getting funds to Australia and apparently there has been a 9 th congress. At least that is what Eric Mills, not known for tellng fibs, confided to me. Why it was shrouded in a veil of mystery remains a puzzle to me .

\section{Conflict of interests}

Author declares that there is no conflict of interest.

\section{Acknowledgments}

None.

\section{References}

1. Carpine-Lancre J.1968, Comptes-Rendus du Premier Congres International de l'Histoire de l'Oceanographie. Publie en tant que No Special 2 du Bulletin de l'Institut Oceanographique de Monaco[Monaco, Editions du Palais Princier]. 1968.

2. Breyne M, Seys J, Lescrauwaert AK, et al. The world's very first marine biology station in Oostende (Belgium). 2010.

3. Charlier RH. More Belgian bio-marine contributions. In: Groeben C, Places, People, Tools. Oceanography in the Mediterranean and Beyond. Proceedings of the eighth International Congress for the History of Oceanography. 2013:106-107.

4. Benson KR, Rehbock PF. Oceanographic History. The Pacific and Beyond. University of Washington, London. 2004.

5. Groeben C. Places, People, Tools. Oceanography in the Mediterranean and Beyond. Proceedings of the eighth International Congress for the History of Oceanography. Giannini Editore, Napoli. 2013:1-14.

6. Lenz W, Deacon M. The fifth international congress of the history of oceanography: the ocean and man. Published as Ergaenzungsheft B2 of the Deutsche Hydrographische Zeitschrift. 1990.

7. Morcos S, Charlier R, Gerges M. Ocean Sciences. Bridging the Millennium. A Spectrum of Historical Accounts. Qingdao, Paris: China Ocean Press \& UNESCO Publishing; 2004.

8. Charlier RH. Fratres in Maribus. Ocean Yearbook. USA: University of Chicago Press; 2005:19-32.

9. Hoevenaghel GT. The first international oceanographic conference (Brussels 1853). Deutsche Hydrographische Zeitschrift, Ergaenzungsheft B22. 1990:330-336. 